Ең алдымен қылмыстық заң талап етіп отырған қылмыстық іске қатысушының негізгі белгілерін қарастыру қажет.

Байқағанымыздай, қылмыстық құқық «қылмыс субъектісі» және «қылмыскердің жеке тұлғасы», «қылмыстық құқықтық қатынас субъектісі» түсініктері бір-бірінен алшақ екендігін білдіреді.

Қылмыс субъектісі - қылмыс құрамы жоқтан тыс, қылмыскердің тұлғасын сипаттайтын минималды белгілердің жиынтығы.

Ал, қылмыскер, қатардағы басқа да адамдар сияқты тұлға.

1. Нақты бір қылмыскерге ғана тән қасиеттер мен сипаттарын зерттеп, оған байланысты оның қылмыстық әрекетінің себебін айтуға болады, алайда бұл тұрғыдан ұылмыстың жалпы себептерін анықтау мүмкін емес. Сондықтан, қылмыскердің тұлғасын топ деңгейінде және «қылмыс субьектісінің» жиынтығы ретінде біртұтастай, яғни типологияны пайдалана отырып зерттеу қажет. Мұндай зерттеуде жасаған қылмысының ұқсастығына және қылмыстық әрекет субьектісінің жеке қасиеттерінің мазмұнына байланысты қылмыскерлердің категориялары мен типтері зерттеледі. Қылмыскер тұлғасын зерттеуде бірден бір күрделі де түбірлі мәселелердің бірі болып қылмыскер тұлғасындағы әлеуметтіктің және биологиялықтың арақатынасы болып табылады.

2. Қорытынды. «Адам» ұғымында оның мәнінің ажырамас әлеуметтік және биологиялық жақтарының бір тұтастығы бекітілген. Тұлға - бұл индивидуалдық, қайталанбастық. «Адам» және «тұлға» түсініктері ажыратылады. Адам ұғымы кең деп саналады, себебі кез келген адам тұлға емес, керісінше кез келген тұлға адам. Тұлға - бұл «адамның әлеуметтік бет бейнесі», қоғамдағы әлеуметтік даму, қалыптасып және өмір сүру процесіндегі оның болмысы. Олай болса біз, «қылмыскердің тұлғасы» деген ұғымды қолданған кезде қылмыс жасаған адамның тек «әлеуметтік бейнесі» деп түсінуіміз қажет.

Қылмыскер тұлғасы - индивидтің қылмыс жасау сипатында көрінетін психикалық ерекшеліктер жиынтығы.

Сайып келгенде, қылмыскердің жеке тұлғасы дегеніміз кім? деген сұрақ өзінен-өзі туады. Қылмыскердің жеке тұлғасы дегеніміз, қылмыскерді бүтіндей алғанда тұлға деп сипаттайтын барлық әлеуметтік қасиеттердің, байланыстар мен қатынастардың жиынтығы болып табылады. Оған айыпталушының әлеуметтік байланысы (саяси, тұрмыстық, еңбек т.б.), дүниетанымы, көзқарасы, психологиялық құрылысы мен ерекшелігі (санасы, еріктілік қасиеті, мінез-құлык ерекшеліктері т.б.), демографиялық және тұлғасының белгілері (жынысы, жасы, денсаулығы т.б.), өмірлік жолы мен тәжірибесі, қоғам алдындағы кінәсі жатады.

Осылайша, қылмыскердің тұлғасы - бұл адамды және оның қоғамдық өмірдің әр түрлі жақтары мен көріністеріндегі әлеуметтік маңызды және индивидуалды белгілердің және басқа да көрсеткіштердің белгілі бір жиынтығы немесе олардың жүйесі болып табылады.

Қылмыстық құқық бұзушының субъектісі туралы іске қатысты мәліметтің жетік болуы, қылмыстық құқық бұзушылықты айқындап, ашып, оның ақиқаттылығына жетуге бірден-бір негіз болады. Әрине, қылмыскердің жеке тұлғасы жөніндегі мәселе көп зерттеулерді талап етеді.

Кез-келген зерттеу жұмысы белгілі бір проблеманы, заман тұрғысына сай талқылап,оны шешуге әрекеттену болып табылады.

\section{Әдебиеттер тізімі}

1. Конституция Республики Казахстан от 30 августа 1995 года// Ведомости Парламента Республики Казахстан.-1996.-№4.- 217.

2. Молдабаев С.С. Проблемы субъекта преступления в уголовном праве Республики Казахстан. Монография. Алматы. 1998.- 8 б.

3. Қазақстан Республикасының Қылмыстық кодексі 2014 жылғы 3 шілдедегі № 226-V ҚР3. Электронды ресурс: https://adilet.zan.kz/

4. Электронды ресурс: https://tolkslovar.ru/p18081.html

5. Отв. ред. Рогов И.И., Балтабаев К.Ж. Криминология. - Алматы: ТОО «Издательство «Норма-К», - 2004 - 53 б.

3.6. Под ред. В.Н.Бурлакова, В.П.Сальникова. СПб.: Криминология - $\mathrm{XX}$ век. СПб.:Юридический центр Пресс, 2000.-203 б.

7. Ратинов А.Р. Судебная психология для следователей. М., «Юрлитинформ» 2001.-56 б.

УДК 342.41

КОНСТИТУЦИОННЫЕ РЕФОРМЫ В РОССИИ В ХХ-ХХІ ВЕКАХ: ОСНОВНЫЕ ЭТАПЫ DOI: $10.31618 /$ ESU.2413-9335.2021.2.93.2.1561

Никифорова Е.Н. кандидат юридических наук, профессор, заведующий кафедрой национальной безопасности и международного права ФГБОУ ВО «Российский государственный гидрометеорологический университет», 


\title{
CONSTITUTIONAL REFORMS IN RUSSIA IN THE 20-21 CENTURIES: MAIN STAGES
}

\author{
E.N. Nikiforova \\ PhD (Law), Professor, \\ Head of Department of National Security and International Law \\ Russian State Hydrometeorological University \\ (federal state-owned publicly-funded institution of higher education), \\ Russia, 192007, St. Petersburg, Voronezhskaya street, 79 \\ I.P. Otto \\ PhD (Technical Sciences), \\ Associate Professor of Department of National Security and International Law \\ Russian State Hydrometeorological University \\ (federal state-owned publicly-funded institution of higher education), \\ Russia, 192007, St. Petersburg, Voronezhskaya street, 79
}

\begin{abstract}
АННОТАЦИЯ
В статье авторы рассматривают основные конституционные реформы, происходившие в России с XIX по XXI век. Первая Конституция РСФСР была принята в 1918 г. V Всероссийским Съездом Советов 10 июля 1918 г. Конституция ознаменовала переход от капитализма к социализму, в ней была закреплена диктатура пролетариата. В 1936 г. была принята Конституция СССР, а в 1937 г. - Конституция РСФСР. В 1977 году была принята Конституции СССР, а в 1978 году - Конституция РСФСР. Конституция РФ 1993 года отразила новую концепцию прав человека, основанную на международных правовых документах.

ABSTRACT

The paper considers the major constitutional reforms that took place in Russia in the 19-21 centuries. The first Constitution of the RSFSR was adopted in 1918 by the 5th All-Russian Congress of Soviets on July 10, 1918. The Constitution commemorated the transition from capitalism to socialism and enshrined the dictatorship of the proletariat. In 1936, the Constitution of the USSR was adopted, followed by the Constitution of the RSFSR in 1937. In 1977, the Constitution of the USSR was adopted, in 1978 - the Constitution of the RSFSR. The Constitution of the Russian Federation adopted in 1993 reflected the new concept of human rights based on the international legal documents.
\end{abstract}

Ключевые слова: конституция, этапы развития страны, международные конституционные нормы, этапы конституционных реформ

Keywords: constitution, country development stages, international constitutional norms, stages of constitutional reforms

\section{Введение}

Для каждой страны исторический путь развития индивидуален - от царской империи к республике, от диктатуры власти к демократии. Опыт государственно-правового развития нашей страны на протяжении многих веков выработал определенные черты, которые позволяют защитить личность от произвола государства, достигнуть оптимального соотношения интересов личности и государства. Первая Конституция РСФСР была принята 10 июля 1918 г. на V Всероссийском Съезде Советов. Конституция ознаменовала переход от капитализма к социализму, в ней была закреплена диктатура пролетариата. В 1936 г. была принята Конституция СССР, а в 1937 г. Конституция РСФСР, которая во многом повторяла основные нормы союзной Конституции.

Конституция (Основной закон) Союза Советских Социалистических Республик была утверждена 7 октября 1977 г. на внеочередной седьмой сессии Верховного Совета СССР 9-го созыва. В Конституции Союза Советских Социалистических Республик были значительно расширены права и свободы граждан. Конституция РФ 1993 г. отразила современную концепцию прав человека, которая основывалась на общепризнанных нормах международного права. Изменения, внесенные в Конституцию РФ в 2014 г., закрепили основные нормы международного права - на «право наций, на самоопределение».

\section{Цель исследования}

Цель данной работы - исследование и комплексный анализ пяти конституций - 1918, 1925, 1937, 1978 годов и Конституции 1993 года соответственно.

Сроки предыдущих конституций РСФСР были последовательно 7, 12, старше 40 и 15 лет, что говорит, учитывая сложный исторический путь развития России, в целом об относительной стабильности конституций.

В данной статье авторы рассматривают этапы конституционного развития России на протяжении XIX-XXI веков. Конституция требует согласия всех граждан. Это должно быть результатом единогласного решения, подписанного всеми гражданами нашей страны, в том числе и граждане России, проживающие в других странах.

Эта существенная особенность конституции по-прежнему признается основной в конституционной теории и практике. Конституции большинства демократических государств мира начинаются со слов: «Мы, народ... принять (провозгласить, установить и т.д.) истинную конституцию».

Актуальность темы исследования Конституция РФ как основной закон государства, 
занимает центральное место в законодательстве Российской Федерации. На современном этапе конституционного развития Российской Федерации в XXI веке с его трудностями и противоречиями продолжается правовая модернизация нашей страны. Поэтому анализ правовых проблем формирования российского конституционализма, его нормативных основ и опыт реализации конституционных положений становиться особенно актуальным.

\section{Материал и методы исследования}

Объектами исследования являются конституционные реформы в России с XIX по XXI век.

В качестве теоретической базы исследования, выполненные в данной работе, используются методы исторические, анализа, сравнительные.

Научная новизна - комплексный анализ правовых проблем, решаемых в процессе проведения конституционных реформ в России в период с XIX по XXI век.

В качестве основных источников права авторы использовали Конституции СССР, РСФСР и РФ.

\section{Результаты и обсуждение}

Рассмотрим основные

этапы конституционных реформ в России[1].

В Древней Руси прообразом Конституции можно назвать Русскую Правду. Она являлась сводом основных законов XI века, сохраняла своё значение до XV-XVI веков. Вместе с судебными и административными грамотами составляла писаный Основной закон. Необходимо упомянуть также Устав, Судебник Ивана III и Соборное уложение. Соборное уложение действовало до 1832 года, пока М.М. Сперанским не была проведена кодификация законов Российской империи и был разработан Свод Законов Российской империи. Русские цари, начиная с Александра I (1801-1825), Александра II (1855-1881), до окончания правления Николая II (1917) предпринимали попытки провести конституционные преобразования. Следует отметить, что реформы, проводимые «сверху» в целом носили прогрессивный либеральный характер. 6 мая 1906 года Николай II утвердил свод «Основных государственных законов Российской империи», который фактически стал первой Конституцией России в XX веке. Но реальные конституционные реформы стали проводиться только после Октябрьской социалистической революции 1917 г.

Авторы кратко рассмотрели конституционные реформы, проходившие в России после революции 1917 г. до 2020 г. Тексты конституций и изменений к ним, получены автором Отто И.П. как зарегистрированного пользователя в системе «Информационного правового обеспечения «Гарант»».

В истории Российской Федерации существует пять конституций - 1918, 1925, 1937, 1978 годов и действующая Конституция 1993 года соответственно[2]. Первые четыре конституции РСФСР - это были В них соблюдался принцип преемственности - сохранение основных социалистических ценностей, утверждение советской власти. Советские конституции были классовыми по своему характеру, закрепляли лидерскую роль рабочего класса.

Конституции советского типа были в основном фиктивными. Они провозгласили принципы, которые фактически не были реализованы в жизни: 1) право собственности на власть трудящихся; 2) вся власть Советов; 3) федеральная структура России; 4) реализация гражданами страны политических прав и свобод, закрепленных в конституциях.

Тоталитарное конституционное право, сменившее дореволюционное государственное право после свершения Октябрьской социалистической революции 1917 года, просуществовало до второй половины 80-х гг. ХХ века.

Первая Конституция РСФСР была принята 10 июля 1918 г. на V Всероссийском Съезде Советов[3]. Конституция ознаменовала переход от капитализма к социализму, в ней была закреплена диктатура пролетариата как лидирующего класса.

Основные социально-экономические преобразования в России в ходе проводимых конституционных реформ можно отразить следующим образом. Социальное положение рабочих в Российской империи на начало XX века: 1)продолжительность рабочего дня - от 12 до 14 часов; 2) эксплуатация детского труда (дети старше 12 лет); 3) низкий уровень заработной платы, недостаточный для удовлетворения самых необходимых потребностей семьи; 4) стесненные жилищные условия; 5) отсутствие техники безопасности и др.

Отметим социально-экономическое развитие страны в 1920-е годы: 1)стабилизация экономики и нормализация социальной сферы; 2) трудно разрешимые противоречия между свободами в социальной и экономической сферах; 3) установление диктатуры городского и сельского пролетариата и беднейшего крестьянства; 4) вводится всеобщая трудовая повинность; 5)рабочим и беднейшим крестьянам предоставляется всестороннее и бесплатное образование; 6) земельный фонд страны объявляется общенародным достоянием; 7) леса, недра и воды общегосударственного значения и сельскохозяйственные предприятия объявляются национальным достоянием; 8) переход всех банков в собственность Рабоче-Крестьянского государства; 9) ограничение избирательного права для целой категории граждан, например, для монахов и духовных служителе церквей и религиозных культов, частных торговцев и др.; 10) государственные доходы и расходы РСФСР формируют общегосударственный бюджет как централизованный фонд денежных средств.

В 1922 г. был образован Союз Советских Социалистических Республик, а РСФСР вошла в состав как союзная республика и утратила свою самостоятельность. В СССР государством управлял союзный орган - Центральный Комитет 
Всесоюзной Коммунистической партии большевиков (ВЦК (б)). Государственное право России утратило самостоятельность как отрасль права в 1924 г. с принятием Конституции СССР.

Народ советских республик единодушно принял решение об образовании Союза Советских Социалистических Республик. Союз ССР - это добровольное объединение равноправных народов. Каждая советская республика имеет право свободного выхода из Союза; доступ в Союз открыт всем социалистическим советским республикам как существующим, так и тем, которые возникнуть в будущем.

В 1924 году была принята первая конституция CССР, РСФСР объединилась с другими независимыми республиками СССР, что явилось причиной замены Конституции 1918 года Конституцией РСФСР 1925.

Новым, характеризующим содержание Конституции 1925 года, является следующее.

1. РСФСР вступила в Советский Союз. В соответствии с волей народов РСФСР (ст.3) , которые приняли решение на Х-Российском съезде Советов о создании Союза СССР, РСФСР передает Союзу полномочия, возложенные в соответствии со статьей 1 Конституции СССР на органы власти Союза СССР.

2. В 1936 г. была принята Конституция СССР, а в 1937 г. - Конституция РСФСР, которая во многом повторяла основные нормы союзной Конституции СССР[4].

Конституция этого этапа отличалась следующими особенностями.

1. Конституция сохранили классовую сущность. В связи с ликвидацией эксплуататорских классов было отменено лишение политических прав граждан по социальным мотивам, было введено всеобщее, равное, прямое избирательное право в результате тайного голосования. Статья 127 Конституции РСФСР 1937 года предусматривает равенство граждан «независимо от их национальности и расы».

2. Впервые в Конституцию был включен широкий спектр прав и обязанностей граждан страны. Впервые было закреплено за гражданами страны право на труд. В соответствии с конституцией возможность использования политических прав гарантируется только «в соответствии с интересами трудящихся и в целях укрепления социалистической системы». Эти демократические установки конституции были классово-ориентированными, идеологически ориентированными.

3. Конституция закрепила руководящую роль Коммунистической партии Советского Союза ВКП (б). Статья 126 Конституции СССР 1936 года и соответствующие статьи конституций союзных республик установили, что наиболее активные и сознательные граждане из рядов рабочего класса и других народных активов объединены во Всесоюзную коммунистическую партию (большевиков), которая является передовой линией трудящихся в их борьбе за укрепление и развитие социалистической системы, и представление руководящего ядра всех организаций.

Конституция (Основной закон Союза Советских Социалистических Республик) была утверждена 5 декабря 1936 г. постановлением Чрезвычайного VIII Съезда Советов Союза Советских Социалистических Республик. В статье 1 Конституции провозгласила: «Союз Советских Социалистических Республик есть социалистическое государство рабочих и крестьян»[5]. Каждая союзная республика имела свою Конституцию, учитывающую особенности республики и построенную в полном соответствии с Конституцией СССР.

В стране была установлена диктатура рабочих и крестьян. Экономическую и социальную основу СССР составляют: 1)социалистическая система хозяйства и социалистическая собственность на орудия и средства производства; 2) разрешено мелкое частное хозяйство единоличных крестьян и кустарей, основанное на личном труде и исключающее эксплуатацию чужого труда; 3) охраняется право на жилой дом и подсобное домашнее хозяйство, право личной собственности граждан на их трудовые доходы и сбережения, на предметы домашнего хозяйства и обихода, на предметы личного потребления и удобства; 4) одним из основных принципов является принцип: «кто не работает, тот не ест» (в конституции 1918 г.: «...Не трудящийся, да не ест!»); 5) осуществляется принцип социализма: «от каждого по его способности, каждому - по его труду»; 6) устанавливается единое союзное гражданство для всех граждан СССР; 7) граждане СССР имеют право на отдых, право на материальное обеспечение в старости, а также - в случае болезни и потери трудоспособности, право на бесплатное образование; 8) граждане СССР имеют право на получение гарантированной работы с оплатой их труда в соответствии с его количеством и качеством.

Социально-экономические права, декларированные в Конституции СССР, предоставлялись только гражданам СССР, иностранные граждане могли только рассчитывать на убежище в тех случаях, когда они вели в своих государствах национально-освободительную борьбу (ст.129 Конституции).

В 30-х годах по всей стране прокатились массовые репрессии, которые после смерти Сталина приобрели не такой явный характер, но продолжались в замаскированной виде вплоть до второй половины 80-х годов XX в. Одновременно с закреплением в Конституции социальноэкономических прав гражданина в государстве существовали законы, которые подавляли личные права граждан. Формы подавления проявлялись в следующем:

- включение в Уголовный Кодекс РСФСР статьи 58, 58, 58, 59, которые не только ликвидировали личную свободу граждан, но также приводили к лишение прав на личную собственность; 
- выселение миллионов крестьян, объявленных «кулаками» и соответственно врагами народа, лишение их самих и их семей личной собственности, в ходе коллективизации всей страны Советов;

- под видом контрреволюционной борьбы принудительная депортация населения из прибалтийских республик;

- принудительное переселение народов (ингушей, крымских татар и других национальностей), которые обвинялись в пособничестве оккупантам в годы Великой отечественной войны.

Конституция требует согласия всех граждан. Эта существенная особенность конституции попрежнему признается доминирующей в конституционной теории и практике. Конституции большинства демократических государств мира начинаются со слов: «Мы, народ... принять (провозгласить, установить и т.д.) истинную конституцию».

В советских конституциях такая формула впервые была включена в Конституцию СССР в 1977 году, в Конституцию РСФСР в 1978 году в преамбуле: «...Народ Российской Советской Федеративной Социалистической Республики ...принимает и провозглашает нынешнюю Конституцию» (в последующих изданиях преамбулы эти слова были удалены) [5].

В течение своего 15-летнего срока действия Конституция 1978 года претерпела значительные изменения. Статус РСФСР был закреплен как союзнической республики в составе СССР, а после распада Союза как независимого государства.

В период управления страной Н.С. Хрущевым и Л.И. Брежневым конституционное право претерпело некоторую демократизацию. Попрежнему вся власть принадлежала коммунистической партии, а приоритет прав и свобод человека игнорировался. Преобразования государственно-правовых институтов начались после ХХ съезда КПСС (1956 года), были отменены некоторые принципы функционирования сталинской системы, однако сохранился тоталитарная форма правления.

Конституция (Основной закон) Союза Советских Социалистических Республик была принята на внеочередной седьмой сессии Верховного Совета СССР девятого созыва 7 октября 1977 г. В ней были значительно расширены права и свободы граждан, большинство из которых вошли в состав основных прав и свобод граждан РФ. В ст.1 Конституции была определена форма государства; «Союз Советских Социалистических Республик есть социалистическое общенародное государство, выражающее волю и интересы рабочих, крестьян и интеллигенции, трудящихся всех наций и народностей страны». Вся власть в СССР принадлежала народу.

Конституция сохранила построенную еще Иосифом Сталиным систему антидемократической власти в стране, но попыталась расширить перечень гражданских прав и свобод. Всему советскому народу объявили о начале всемирно-исторического поворота человечества от капитализма к социализму. «Утвердилась общественная собственность на средства производства, подлинная демократия для трудящихся масс. Впервые в истории человечества было создано социалистическое общество».

Экономическая система СССР развивалась на основе коллективной и государственной собственности, собственности советских граждан, Социальную основу СССР составлял нерушимый союз рабочих, крестьян и интеллигенции. В Конституции появляется и интеллигенция как класс, которая ранее считалась прослойкой в обществе, и не пользовалась почти никакими правами. В стране стали развиваться государственные системы здравоохранения, социального обеспечения, торговли и общественного питания, бытового обслуживания и коммунального хозяйства.

В октябре 1991 г. Верховный Совет РСФСР утвердил экономическую программу (программа «Шоковой терапии»). Основная цель данной программы, которую возглавил Е.Т. Гайдар переход к рыночной экономике: 1) либерализация цен; 2) приватизация жилого фонда, т.е. передача государственной собственности в частные руки. Либерализация цен (1 января 1992 г.) привела к подорожанию промышленных

и продовольственных товаров. С 1990 г. по 1997 г. цены выросли в 10000 раз. В стране наблюдался спад производства и тотальный дефицит всех товаров, в том числе и продуктов питания.

В эти годы сформировался слой финансовой олигархии, которых не интересовали нужды народа и всей страны. 1 июля 1994 г. начался второй этап приватизации - денежный.

Отметим последствия «Шоковой терапии»: 1) сформировался рынок промышленных и продовольственных товаров; 2) сокращение поступлений налогов в бюджет и, как следствие, огромный бюджетный дефицит; 3) массовое обнищание населения; 3) криминализация общества; 5)подорожание природных ресурсов. Команда Гайдара поставила над страной ничем не обоснованный экономический эксперимент, который привел к углублению экономического кризиса в стране.

В стране возникает в 90-х годах «кризис неплатежей». Предприятия не могут расплачиваться по своим обязательствам, систематические задержки выплаты заработной платы трудящимся из-за отсутствия денежных средств на банковских счетах. Гибнет слаборазвитая отечественная легкая промышленность. Значительно возрастает доля импорта. Пострадали учреждения бюджетной сферы; научные, медицинские и образовательные учреждения. Молодые ученые массово покидают страну, уезжают в США, Голландию, Великобританию и другие страны. Был нанесен значительный ущерб военно-промышленному 
комплексу страны. Возникла угроза безопасности для всей России.

Период становления конституционное право современной России начался после перестройки, развитие которого продолжается в XXI в.

21 сентября 1993 г. Б.Ельцин подписал указ о поэтапной конституционной реформе. Был проведен всенародный референдум по вопросу принятия новой Конституции России. Конституция Российской Федерации была принята всенародным голосованием 12 декабря 1993 г. [6]. Новый Основной закон страны ликвидировал советскую систему власти. Форма государства была закреплена в 1 ст. Конституции РФ: «Российская Федерация - Россия есть демократическое федеративное правовое государство с республиканской формой правления».

Конституция РФ определяет конституционный статус человека и гражданина в государстве и обществе. Важнейшими составными частями конституционного статуса личности являются основные права, свободы, законные интересы и обязанности. Группа экономических прав занимает одно из главных мест в основном законе российского государства. Конституция РФ впервые в истории России признала гражданина в качестве самостоятельного субъекта общества. Права и свободы человека являются высшей ценностью в России.

Конституция РФ 1993 г. отразила новую концепцию прав человека, основанную на общепризнанных нормах международного права и международных договорах. Согласно этой концепции, государство должно обеспечить такой уровень экономических прав и свобод личности, который закреплен в международных стандартах.

Наиболее действенной гарантией прав и свобод является правосудие. В ст.46 Конституции «каждому гарантируется судебная защита его прав и свобод». Каждый вправе обращаться в международный суд, если он не смог защитить свои права в своем государстве.

Страна и весь народ переживала тяжелые в экономическом и социальном плане времена (за исключением олигархов). Россия постепенно, стала возрождаться, стал формироваться и укрепляться внешний и внутренний суверенитет. Авторы считают, что основная заслуга принадлежит нашему президенту, В.В. Путину [7]. Авторы родились, учились, работали, занимались и занимаются наукой как при советской власти, так в современной России. У каждого периода исторического развития страны есть свои достоинства и недостатки. Но мы сейчас живем в правовом государстве. Это должны понимать граждане страны, должны повышать свою юридическую грамотность.

В начале XXI века в России произошли следующие экономические реформы: 1) пенсионная (2002 г., хотя сейчас критикуют очередную проводимую пенсионную реформу); 2) банковская (2001-2004), налоговая (2000-2003); 3) монетизация льгот (2005); 4) увеличение иностранных инвестиций на фоне оттока капитала из России.

\section{Выводы}

В истории Российской Федерации действовали пять конституций - 1918, 1925, 1937, 1978 годов и действующая Конституция 1993 года. Конституционная реформа в РФ продолжалась до 2020 г.

В течение 2020 г. до всенародного голосования 1 июля 2020 г. весь народ обсуждал предложения по внесению в Конституцию РФ изменений. Предложения по внесению изменений касались с 1 по 8 глав Конституции. Предложения состояли в следующем:

В ходе Послания Федеральному собранию Президент предложил закрепить в Конституции изменения по 10 пунктам:

1. Приоритет Конституции РФ над международным правом на территории страны.

2. Ужесточение требований к кандидатам на президентский пост.

3. Запрет на иностранное гражданство или иностранный вид на жительство для представителей власти.

3. Изменение роли парламента.

4. Изменения в назначении руководителей силовых ведомств и прокуроров регионов. Теперь такие назначения Президент сможет сделать только по результатам предварительных консультаций с Советом Федерации. Закрепление в Конституции РФ социальных гарантий и др.

Общероссийское голосование по вопросу одобрения изменений в Конституцию Российской Федерации проводилось с 25 июня по 1 июля 2020 года. Последний - основной - день голосования (среда) был объявлен выходным. 77,92\% граждан подержали поправки в конституцию РФ при явке в $67,97 \%$.

Изменения коснулись только глав с 3 по 8 главу.

В процессе обсуждения и всенародного голосования были внесены изменения в следующие статьи: 1) статья 67 изменена часть 1;2) статья 68; 3)статья 69 (о правах коренных народов); 4) пункт 2 статьи 70 (о столице России); 5) статья 71 (о ведомствах России); 6) статью 72 (о ведении РФ и субъектов); 7) статья 81 (об избрании Президента) и другие.

Путин оценил принятые поправки к Конституции РФ: «Будут укреплять нашу государственность»[7].

Формирование правового российского государства продолжается. Мы обращаем внимание на то, что наше будущее поколение будет продолжать реформы, которые способствуют дальнейшему развитию правового государства в современной России.

\section{Список литературы}

1. Отто И.П. Конституционное развитие Франции и России в XVIII-XX веках // В сборнике: Россия и Франция: 125 лет дружбы и сотрудничества. Материалы международной 
научной конференции. Ответственный редактор А.М. Судариков. 2019. С.155-162.

2. Никифорова Е.Н., Отто И.П. Правоведение: краткий курс лекций. - Санкт-Петербург: РГГМУ, 2020.

3. Конституция (Основной закон) Российской Социалистической Федеративной Советской Республики (принята V Всероссийским Съездом Советов в заседании от 10 июля 1918 г.) (Электронный периодический справочник) // Система Гарант «Гарант-Классик» (мобильный).

4. Конституция (Основной закон) Союза Советских Социалистических Республик (утверждена постановлением Чрезвычайного VIII Съезда Советов Союза Советских Социалистических Республик от 5 декабря 1936 г.) (Электронный периодический справочник) // Система Гарант «Гарант-Классик» (мобильный).
5. Конституция (Основной закон) Союза Советских Социалистических Республик (принята на внеочередной седьмой сессии Верховного Совета СССР девятого созыва 7 октября 1977 г.) (Электронный периодический справочник) // Система Гарант «Гарант-Классик» (мобильный).

6. Конституция Российской Федерации (принята всенародным голосованием 12 декабря 1993 г.) (с поправками и изменениями, одобренными в ходе общероссийского голосования 1 июля 2020 года) (Электронный периодический справочник) // Система Гарант «Гарант-Классик» (мобильный).

7. Президент Российской Федерации: Официальный сайт. [Электронный ресурс]. URL: http://state.kremlin.ru (3 июля 2020).

УДК 725.8:347.214.2

ГРНТИ 10.27

\title{
ПЛОСКОСТНОЙ СТАДИОН КАК ОБЪЕКТ НЕДВИЖИМОСТИ
}

DOI: 10.31618/ESU.2413-9335.2021.2.93.2.1562

Половцев И.Н.

Главный инженер ГАОУ ВО ЛО

«Ленинградский государственный университет им.А.С.Пушкина», 196605, Санкт-Петербург, Пушкин, Петербургское шоссе, 10

\section{FLAT STADIUM AS A REAL ESTATE}

I.N. Polovtsev

Chief Engineer of Leningrad State University after A.S.Pushkin, 196605, Saint-Petersbug, Pushkin, Peterburgskoe sh., 10 ORCID 0000-0002-7689-5395

\begin{abstract}
АННОТАЦИЯ
Статья посвящена вопросу возможности отнесения к объектам капитального строительства и к объектам недвижимости плоскостного стадиона. Автор на основе анализа общего и специального законодательства приходит к выводу, что объект спорта - плоскостной стадион должен являться объектом недвижимости. Его позиция подкрепляется актуальными письмами Министерства строительства и жилищно-коммунального хозяйства и Федеральной службы государственной регистрации, кадастра и картографии.
\end{abstract}

\section{ABSTRACT}

The article is devoted to the question of the possibility of attributing a flat stadium to capital construction objects and real estate objects. Based on the analysis of general and special legislation, the author comes to the conclusion that a sports object - a flat stadium should be a real estate object. His position is supported by current letters from the Ministry of Construction, Housing and Utilities and the Federal Service for State Registration, Cadastre and Cartography.

Ключевые слова: плоскостные спортивные сооружения, недвижимое имущество, улучшения земельного участка, объекты гражданских прав, правовой режим, объект недвижимости, объект капитального строительства, регистрация прав собственности, спортивное сооружение, стадион. stadium.

Keywords: real estate object, capital construction object, registration of property rights, sports facility,

Под понятием «стадион» понимается место занятий спортом и физической культурой, а также место проведения массовых спортивных соревнований. Для многих организаций, например для образовательных, является важным не только физическое наличие стадиона, но и возможность оформить его как объект недвижимости, находящийся в их владении и пользовании.
Безусловно, если под понятием «стадион» понимается некоторый архитектурно оформленный объект (здание или группа строений), например такие, как стадион «Лужники» в Москве [1], «Петровский» в Санкт-Петербурге [2], «Фишт» в Сочи [3] или «Альянц-Арена» в Мюнхене, то не возникает вопросов о том, следует ли относить 